\title{
Guide snoRNAs: Drivers or Passengers in Human Disease?
}

\author{
Manisha Deogharia ${ }^{1,+}$ and Mrinmoyee Majumder ${ }^{2, *,+}(\mathbb{D}$ \\ 1 Department of Anatomy and Structural Biology, Albert Einstein College of Medicine, \\ Bronx, New York, NY 10461, USA; manisha.deogharia@einstein.yu.edu \\ 2 Department of Biochemistry and Molecular Biology, \\ College of Medicine, Medical University of South Carolina, Charleston, SC 29425, USA \\ * Correspondence: majumder@musc.edu \\ + These authors contributed equally.
}

Received: 25 October 2018; Accepted: 18 December 2018; Published: 20 December 2018

\begin{abstract}
In every domain of life, RNA-protein interactions play a significant role in co- and post-transcriptional modifications and mRNA translation. RNA performs diverse roles inside the cell, and therefore any aberrancy in their function can cause various diseases. During maturation from its primary transcript, RNA undergoes several functionally important post-transcriptional modifications including pseudouridylation and ribose $2^{\prime}-O$-methylation. These modifications play a critical role in the stability of the RNA. In the last few decades, small nucleolar RNAs (snoRNAs) were revealed to be one of the main components to guide these modifications. Due to their active links to the nucleoside modification, deregulation in the snoRNA expressions can cause multiple disorders in humans. Additionally, host genes carrying snoRNA-encoding sequences in their introns also show differential expression in disease. Although few reports support a causal link between snoRNA expression and disease manifestation, this emerging field will have an impact on the way we think about biomarkers or identify novel targets for therapy. This review focuses on the intriguing aspect of snoRNAs that function as a guide in post-transcriptional RNA modification, and regulation of their host genes in human disease.
\end{abstract}

Keywords: snoRNA; RNA modification; box C/D; box H/ACA; 2'-O-methylation; pseudouridine; human disease

\section{Introduction}

Nuclear RNA undergoes numerous nucleoside specific post-transcriptional modifications. Copious evidence now exists to show that critical cellular processes such as maturation of RNA, stabilization of RNA 3D structure, ribosome assembly, protein translation, and recognition steps of tRNAs are dependent on the presence of modified nucleosides on RNA that are conserved from bacteria to humans [1-6]. Over 100 chemically distinct modified nucleosides have been identified to date [7]. In RNA, methylation of the ribose moiety at the 2'-hydroxyl group (Figure 1A) and conversion of uridines into pseudouridines ( $\Psi$ ) (Figure 1B) are the two most prevalent post-transcriptional modifications. These modifications can occur by 1) guide RNA dependent or 2) guide RNA independent (protein only) mechanisms. Eukaryotic small nucleolar RNAs (snoRNAs) are a group of non-coding RNAs that function as the "guide" in the guide RNA dependent RNA modifications. These guide RNAs are required to bind to specific complementary sequences on the substrate RNAs to form a guide-target duplex where a target nucleoside is modified by the RNA binding proteins (RBP), serving as enzymes. These 60-300-nucleotide-long RNAs are primarily located in the nucleolus (snoRNAs) or nucleoplasmic Cajal bodies (small Cajal body-specific RNAs, scaRNAs), a nuclear sub-organelle that 
is enriched in RNA and RBPs [8]. These snoRNAs can be classified into two major groups based on specific structural features (i) box C/D (Figure 1C) and (ii) box H/ACA (Figure 1E) [9]. To function as a guide, snoRNAs form small nucleolar ribonucleoprotein (snoRNP) complexes with RBPs along with accessory proteins. 2'-O-methylation is produced by box C/D snoRNAs which associate with four core proteins: Fibrillarin, NOP56, NOP58, and $15.5 \mathrm{kDa}$ (Snu13p in yeast, L7Ae in archaea) (Figure 1D), where Fibrillarin is the methyltransferase [10]. Box H/ACA snoRNA forms RNP complex with dyskerin (NAP57 in mammals, CBF5 in yeast and archaea), GAR1, NOP10, and NHP2 (L7Ae in archaea) (Figure 1F) to guide $\Psi$-formation in RNA where dyskerin (DKC1) is the pseudouridine synthase $[11,12]$.

A

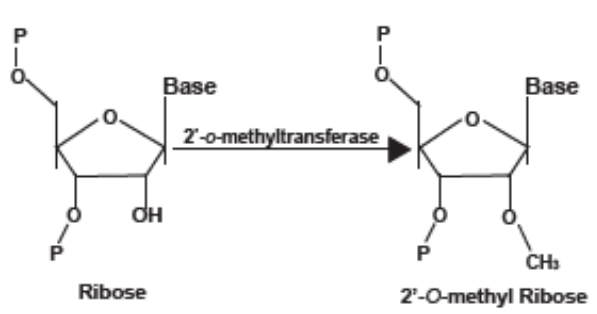

C

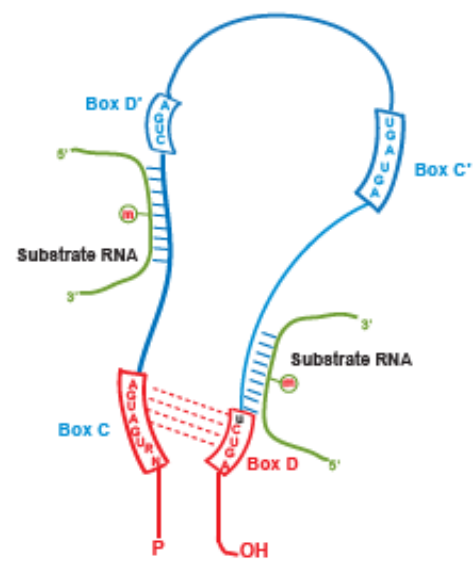

E

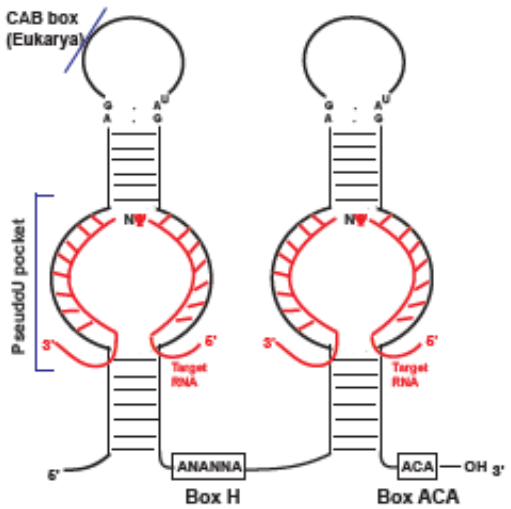

B

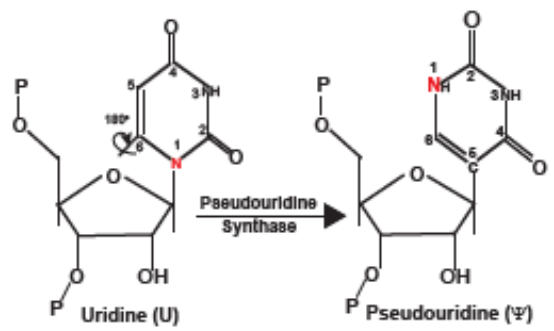

D

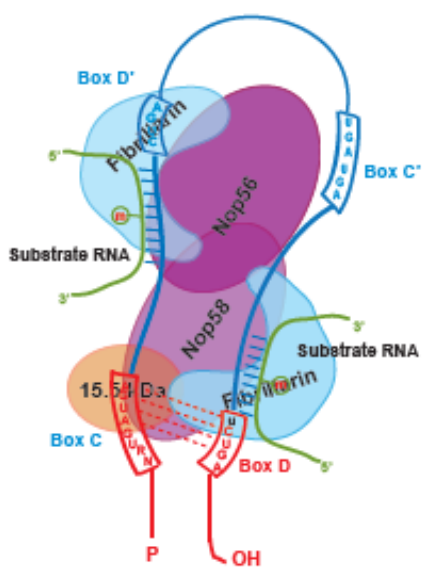

$\mathbf{F}$

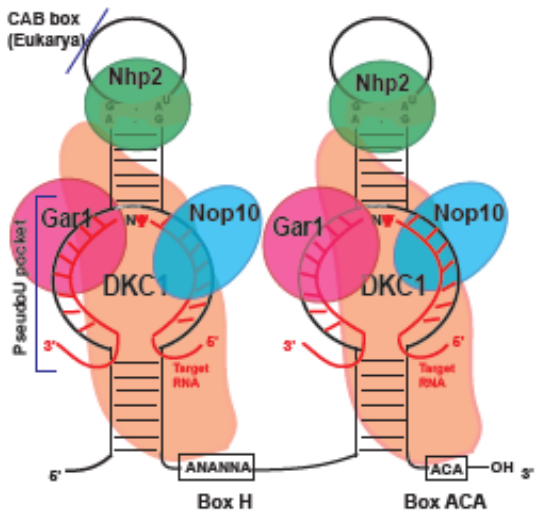

Figure 1. snoRNA guided modifications and machinery. (A) Schematic representation of a 2'-O-methylated ribose. The 2'-OH group of ribose sugar is $\mathrm{O}$-methylated either by a stand-alone methyltransferase or by box C/D guide RNPs. (B) Schematic representation of pseudouridine ( $\Psi$ ). $\Psi$ is a rotational (C-5 ribosyl) isomer of uridine (U), in which the $\mathrm{C}-\mathrm{C}$ glycosidic bond is broken to form an $\mathrm{N}-\mathrm{C}$ bond. (C) The secondary structure of a box C/D snoRNA. Boxes C, D (red), C', and D' (blue) are shown here. " $\mathrm{m}$ " represents the target 2'-O-methylation site that is always the fifth nucleotide from 
box D or D'. (D) Eukaryal box C/D snoRNP with all the protein components including methyl transferase Fibrillarin (light blue), NOP56 (dark violet), NOP58 (light violet)) and asymmetrically bound $15.5 \mathrm{kDa}$ only at the C/D box (orange). (E) Schematic of a eukaryal box H/ACA pseudouridylation guide snoRNA. CAB box is found at the apical loop in some eukaryotic box H/ACA RNAs. The conserved box H (ANANNA) and ACA motifs are located at the 3' end of the 5'- and 3'hairpin unit, respectively. Base-pairing of the target RNA (red) with complementary sequences in the pseudouridylation pocket positions the unpaired substrate uridine at the tip of the pocket. The approximately 14-16-nucleotide distance between the modified nucleotide ( $\Psi$ ) and box ACA (or H) is somewhat maintained. (F) Structure of a box H/ACA snoRNP. DKC1 (orange) interacts with box ACA or box $\mathrm{H}$, the pseudouridylation pocket, and NOP10 (sky blue) and GAR1 (pink). As eukaryal box H/ACA RNAs lack kink turn near the apical loop like their archaeal counterpart, NHP2 (green) interacts with the preformed box H/ACA snoRNP in the presence of guide-DKC1-NOP10-GAR1.

snoRNAs are mostly generated from mRNA intronic regions, without a 5'-cap [13], after concomitant splicing, debranching, and trimming [14-16]. Additionally, a subset of snoRNAs is also generated from intergenic locations and independent promoters (contain 2,2,7-trimethylguanosine (TMG) cap structure) [17]. Specific non-intronic genes are found to code for important snoRNAs like $\mathrm{U} 3, \mathrm{U} 8$, and $\mathrm{U} 13$ that play a role in pre-rRNA endonucleolytic process. Genes harboring snoRNAs in their introns are called host genes $[8,18]$. There are over 200 different host genes present, out of which some are also non-protein-coding genes with short and poorly conserved open reading frames [14]. These non-protein coding host genes were thought to have no function other than to carry the snoRNA-encoding sequences in their introns [19]. However, recent data suggest a functional role for these host genes. For example, a mouse noncoding RNA Zfas1 gene intronically hosts three box C/D snoRNA [20]. Zfas1 is down-regulated in ductal carcinoma tumor tissues. Knockdown of this RNA in mouse carcinoma cell line shows an increase in different cell proliferation and differentiation markers, although the levels of snoRNAs generated from this RNA remain relatively constant [20].

The protein-coding host genes are involved in nucleolar function, ribosome structure formation, and protein synthesis [21]. The host genes are also of particular importance and physiologically pertinent as their intronic snoRNAs eventually participate in ribosome biogenesis [8,21]. Interestingly, in humans, many of the host genes belong to a family of terminal oligopyrimidine (TOP) genes [22]. This set of genes codes for proteins involved [19] in transcription, translation, and growth-dependent regulation $[17,22]$.

In recent years, independent studies using various approaches have concluded that apart from their housekeeping role, snoRNAs also control cell fate and oncogenesis [23-27]. There are very informative reviews available discussing the different roles of snoRNAs or RNA modifications, and disease $[8,28,29]$. However, the primary scope of this review is to unite the guide RNAs and their host genes, with abnormalities in expression that are primarily or secondarily responsible for human diseases.

\section{Box H/ACA Guide RNAs in Human Disease}

Pseudouridine $(\Psi)$ was discovered in 1951 as the most abundant post-transcriptionally modified nucleotide, and in 1959 it was chemically characterized [30]. Later in the '90s, different laboratories pioneered in identifying the small nucleolar RNAs that guided the isomerization of uridine into $\Psi$ [31,32]. This subclass of snoRNAs consists of specific structural features called box $\mathrm{H} / \mathrm{ACA}$ (box $\mathrm{H}$, a variant of box ACA, ANANNA and box ACA, ACANNA; N: any nucleotide) in a double hairpin (60-75 long each) connected by a hinge region (Figure 1E). The distance between the target uridine and the box H or box ACA of the guide RNA is around $14 \mathrm{nt}$. Additionally, box H/ACA scaRNAs in eukaryotes carry a Cajal body localization signal called CAB box (consensus of ugAG) in the terminal loop of either their 5'- or 3'-hairpins (Figure 1E) [33]. RNA guided pseudouridines are found on various types of RNAs, majorly rRNAs along with spliceosomal snRNAs [34-36]. Interestingly, 
recently characterized nucleoplasmic AluACA RNAs with unknown function, derived from intronic Alu elements, show a similarity in structure to that of box H/ACA scaRNAs [37].

Large subunit (LSU: 28S, 5.8s, and 5S) and small subunit (SSU: 18S) rRNAs are the two major RNA components of the ribosome where around 100 uridines are converted to pseudouridines by box H/ACA snoRNPs [33,38]. For example, the RNA encoded by snoRA12 guides $\Psi$ formation at position 372 on $28 \mathrm{~S}$ rRNA and snoRA24 (ACA24) modifies positions 609 and 863 on 18S rRNA. Moreover, the two most conserved $\Psi$ s on 28S rRNA are modified by snoRA74 (U19) at least in the higher eukaryotes (also see Section 2.1). $\Psi$ s are known to provide structural stability to the modified RNAs [39] that are required for the biogenesis of ribosome [40]. In the sections below, we describe the box H/ACA guide RNAs and their host genes that are connected to numerous diseases due to their aberrant expression. We have extensively used databases and literature $[15,16,41-43]$ to check for all the predicted and verified modifications to date.

\subsection{Box H/ACA Guide RNAs in Cancer}

Studies show that pseudouridines can be found at functionally critical positions on the rRNAs $[3,38,42,43]$. Thus, it can be projected that deregulation of box H/ACA snoRNAs that guide $\Psi$ formation can be involved in cancer [44]. For example, one of the recently identified snoRNAs (h5sn2) with box H/ACA features shows a drastic reduction in expression in meningioma compared to the healthy brain [45]. Meningioma, the most common kind of slow-growing brain tumor, is found in the meninges, the membranes that edge the brain and spinal cord. snoRNA h5sn 2 shows a sequence complementarity to human $5 S$ rRNA.

While the loss of h5sn2 shows a potential tumorigenic activity, snoRA42 is overexpressed in non-small cell lung cancer (NSCLC), one of the primary causes of cancer deaths across the world [46]. snoRA42 is highly expressed in colorectal cancer as well [47]. This study also shows that over-expression of snoRA42 induces cell proliferation, migration, invasion, and tumorigenicity in colorectal cancer [47]. snoRA21 shows oncogenic properties in human colorectal cancer as well [48].

Expression of two other snoRNAs, snoRA47 and ACA11, are also high in hepatocellular carcinoma tissues compared to normal tissues [49,50]. snoRA74 (U19), responsible for modifying the two most conserved $\Psi$ s on $28 \mathrm{~S}$ rRNA, 3741 and 3743 is found to be up-regulated in gallbladder cancer [51]. These positions are conserved from bacteria (protein only modification) to humans $[1,38,41]$. Both $\Psi \mathrm{s}$ are located at a central region of the ribosome called the decoding center which is responsible for contacting the passing tRNAs [41]. Irregular expression of a group of box H/ACA snoRNAs has also been shown in hematological disorders like acute myeloblastic and lymphoblastic leukemia, T-cell lymphoma and multiple myeloma [52-55].

To date, there is no direct evidence of either deregulation of a particular snoRNA guided modification or mere presence or absence of modification as a sole cause of any disease. However, in head and neck squamous cell carcinoma (HNSCC) a different form of snoRA71C is found with an A60 $>$ G60 nucleotide mutation in the box $\mathrm{H}$ region. This substitution seems to alter the guide-target base pairing that is required to modify position 406 on $18 \mathrm{~S}$ rRNA $[29,56]$. We can speculate that this A to $G$ alteration followed by a lack of modification can indeed be the cause or a trigger in HNSCC initiation or progression.

Additionally, box H/ACA scaRNAs that modify spliceosomal RNAs are also associated with cancer when deregulated. For example, scaRNA3, also known as HBI-100, is found to be up-regulated in breast cancer [57]. Several other box H/ACA guide RNAs, associated with cancer are listed in Tables 1 and 2.

\subsection{Box H/ACA Guide RNAs in Genetic Disease}

Apart from cancer, box H/ACA RNAs are also associated with genetically inherited diseases when altered. A subset of snoRNAs is down-regulated in a bone marrow failure syndrome called X-linked dyskeratosis congenita (X-DC) [29,52-55,58]. DC (X-DC, and two other subtypes of DC-autosomal 
dominant or autosomal recessive), is a congenital disorder with defects including bone marrow failure, skin abnormalities, hematopoietic malignancies, and pulmonary fibrosis [52,59]. A study by Bellodi et al. shows that some box H/ACA snoRNAs like snoRA15, snoRA24, snoRA31, snoRA48, snoRA56, and snoRA67 are down-regulated in fibroblasts or lymphoblast cells expressing mutant $D K C 1$ as found in X-DC patients [29,52]. scaRNA U93 is down-regulated in the majority of the X-DC patients' cells tested except CD34+ hematopoietic progenitor cells with $D K C 1$ promoter mutation at position C-141 to G (c.-141, C>G) [52]. However, snoRA42 is found to be significantly up-regulated in lymphocytes expressing $D K C 1$ with N-terminal L37 deletion ( $\triangle$ L37). Interestingly, these H/ACA snoRNA guided modifications are found mostly within two distinct regions of the ribosome which include domain II of 28S rRNA and expansion segment 6 (ES6) on 18S rRNA [60]. The same study by Bellodi et al. also shows a reduction in $\Psi$ formation at 109, 119, 572,1367, and 1445 residues on $18 \mathrm{~S}$ rRNA by using liquid chromatography-tandem mass spectrometry (LC-MS/MS) [52]. The reduction in $\Psi$ s is found in fibroblasts with $D K C 1(\triangle \mathrm{L} 37)$ or lymphoblasts with $D K C 1$ mutation at position T66 to A (T66A) where a decrease in their respective guide RNAs is also observed except for snoRA42.

Box H/ACA guide RNAs are also involved in a genetic disorder called tetralogy of Fallot (TOF or "TET") in infants. TOF is a condition of numerous related congenital heart defects that are present at birth. It occurs due to abnormal development of the fetal heart during the first eight weeks of pregnancy. Three box H/ACA scaRNAs, scaRNA1, scaRNA4, and scaRNA8, have been found to be down-regulated in TOF in a recent study by Nagasawa et al. [61]. These scaRNAs are responsible for U2 snRNA modification.

\subsection{Box H/ACA Guide RNA Host Gene Deregulation in Disease}

Evidence to date suggests that apart from a handful of snoRNAs, many of the altered box H/ACA snoRNA expression in different disorders is independent of the host gene transcription [53,54]. The evidence supports either of two hypotheses: box H/ACA snoRNA deregulation can directly associate with a disease devoid of the host gene modulation, or the regulation between host genes and their intronic snoRNAs is yet to be identified. However, there are ample examples of host gene deletion or mutation causing disease of which some cases may show an alteration in their intronic box H/ACA RNAs [27]. For example, two box H/ACA-type snoRNA genes, snoRA6 and snoRA62 are encoded from the host gene RPSA or Laminin receptor (LAMR). These RNAs modify positions 3616 and 3830 on $28 S$ rRNA [38]. There are mutations found in the LAMR/RPSA gene which can be linked to congenital asplenia, a dysfunction of the spleen [62]. Future studies will be needed to show if RPSA mutations impact these snoRNA expressions.

Another ribosomal protein-coding gene RPL5, where over 15 different mutations have been identified so far, is associated with Diamond-Blackfan anemia (DBA), an inherited bone marrow failure syndrome [63]. RPL5-mutation induced pluripotent stem cells (iPSCs) from DBA patients exhibit defective $60 \mathrm{~S}$ ribosomal subunit assembly, accumulation of $12 \mathrm{~S}$ pre-rRNA, and impaired erythropoiesis [64]. RPL5 hosts snoRA66 which guides $\Psi 119$ on $18 \mathrm{~S}$ rRNA. Not much work has been done to show if there is a correlation between RPL5 mutation and snoRA66 expression followed by $\Psi 119$ formation. Interestingly, as mentioned in Section 2.2, X-DC patients' cells show a decrease in $\Psi 119$ formations in lymphocytes and fibroblasts expressing DKC1 (T66A) and DKC1, respectively [52]. Additionally, snoRA66 is also down-regulated in both cells expressing mutant DKC1. Like X-DC, it would be intriguing to see if snoRA66 expression and $\Psi 119$ formation are also regulated along with RPL5 in DBA.

Additionally, $D K C 1$, where mutations are found in almost all X-DC patients, also acts as the host gene for snoRA36 and snoRA56 $[59,65]$. DKC1 mutations not only affect its protein expression and function in DC patients, but they may also affect the expression of these two snoRNAs. snoRA36 and snoRA56 modify positions 105 and 1244 on $18 \mathrm{~S}$ and 1664 on $28 \mathrm{~S}$ and 296 on 18S rRNA, respectively $[52,59,65]$. DKC1 is often down-regulated in DC along with certain snoRNAs (see Section 2.2) $[52,59,65]$. Though reports exist suggesting that $D K C 1$ exerts its function independent of 
the snoRNAs that it hosts, further investigation is necessary to test this link. It is possible that both host genes and their intronic snoRNAs may be relevant under specific cellular conditions.

Table 1. Box H/ACA guide snoRNAs in human disease.

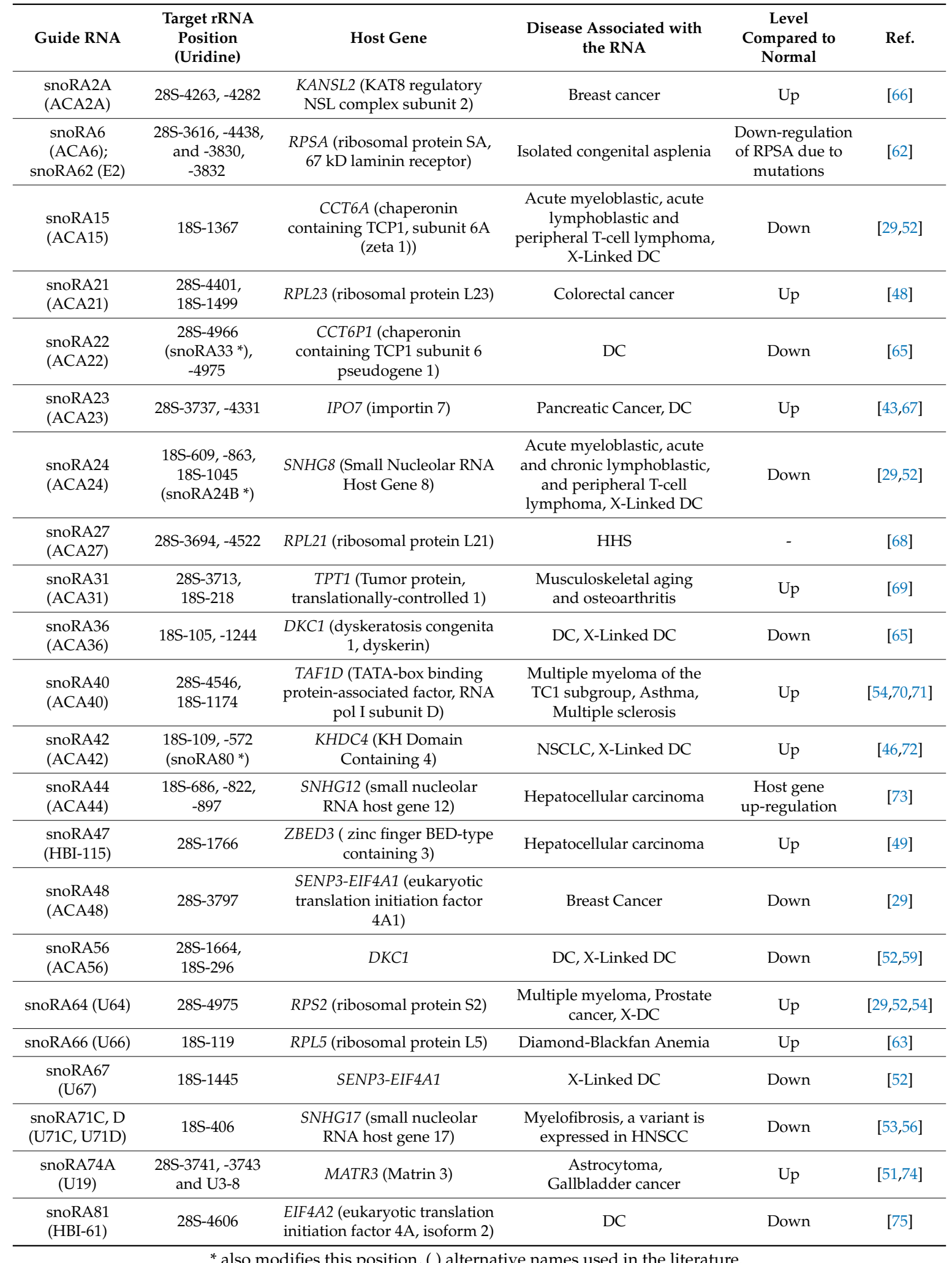

* also modifies this position, ( ) alternative names used in the literature. 
Table 2. Box H/ACA guide scaRNAs in human disease.

\begin{tabular}{|c|c|c|c|c|c|}
\hline Guide RNA & $\begin{array}{l}\text { Target snRNA } \\
\text { Position } \\
\text { (Uridine) }\end{array}$ & Host Gene & $\begin{array}{l}\text { Disease Associated } \\
\text { with the RNA }\end{array}$ & $\begin{array}{l}\text { Level } \\
\text { Compared to } \\
\text { Normal }\end{array}$ & Ref. \\
\hline $\begin{array}{l}\text { scaRNA1 } \\
\text { (ACA35) }\end{array}$ & U2-89 & $\begin{array}{c}\text { PPP1R8 (protein } \\
\text { phosphatase } 1 \text { regulatory } \\
\text { subunit } 8 \text { ) }\end{array}$ & $\begin{array}{l}\text { Tetralogy of Fallot } \\
\text { (TOF), a heart } \\
\text { condition in children }\end{array}$ & Down & [61] \\
\hline $\begin{array}{l}\text { scaRNA4 } \\
\text { (ACA26) }\end{array}$ & U2-41 & $\begin{array}{l}\text { KHDC4 (KH domain } \\
\text { containing 4, pre-mRNA } \\
\text { splicing factor) }\end{array}$ & TOF & Down & {$[61,76]$} \\
\hline scaRNA8 (U92) & U2-34, $-43,-44$ & $\begin{array}{l}\text { HAUS6 (HAUS augmin } \\
\text { like complex subunit } 6 \text { ) }\end{array}$ & TOF & Down & {$[61,76]$} \\
\hline $\begin{array}{l}\text { scaRNA11 } \\
\text { (ACA57) }\end{array}$ & U5-43 & $\begin{array}{l}\text { CHD4 (Chromodomain } \\
\text { helicase DNA binding } \\
\text { protein } 4 \text { ) }\end{array}$ & $\begin{array}{l}\text { Sifrim-Hitz-Weiss } \\
\text { syndrome }\end{array}$ & $\begin{array}{l}\text { Host gene } \\
\text { mutation }\end{array}$ & [77] \\
\hline $\begin{array}{l}\text { scaRNA13 } \\
\text { (U93) }\end{array}$ & U2-54, U5-51 & $\begin{array}{l}\text { SNHG170 (small nucleolar } \\
\text { RNA host gene 170) }\end{array}$ & $\begin{array}{l}\text { DC, Congenital heart } \\
\text { defects }\end{array}$ & Down & [58] \\
\hline $\begin{array}{l}\text { scaRNA23 } \\
\text { (ACA12) }\end{array}$ & U6-40 & $\begin{array}{c}\text { COP1 (COP1, E3 ubiquitin } \\
\text { ligase) }\end{array}$ & Breast Cancer & UP & [57] \\
\hline
\end{tabular}

( ) alternative names used in the literature.

We summarize the box H/ACA snoRNAs and scaRNAs with validated or predicted targets and the snoRNA host genes that are associated with human disease in Tables 1 and 2.

\section{Box C/D Guide RNAs in Human Disease}

Another post-transcriptional modification, guided by snoRNAs, is the 2'-O-methylation of the ribose sugar. This modification is brought about by box C/D snoRNAs. Box C/D snoRNAs in eukaryotes are characterized by the presence of a consensus box C (RUGAUGA) and box D (CUGA) near the $5^{\prime}$ and $3^{\prime}$ ends of the RNA, respectively (Figure 1C). They also contain imperfect copies of these two boxes, box $\mathrm{C}^{\prime}$ and box $\mathrm{D}^{\prime}$ in between the two $\mathrm{C}$ and $\mathrm{D}$ boxes. The region between the boxes $\left(C\right.$ and $\left.D^{\prime}\right)$ and $\left(C^{\prime}\right.$ and $\left.D\right)$ form base pairing with target RNAs where the snoRNP methylates the 5th nucleotide upstream of $\mathrm{D}$ or $\mathrm{D}^{\prime}$ boxes. Like box H/ACA scaRNAs, box C/D scaRNAs are also found in Cajal Bodies. They do not have a CAB box like box H/ACA scaRNAs, but they contain G.U/U.G wobble stem instead, which helps their translocation to Cajal bodies [78]. Methylation of the 2'- hydroxyl group favors the C3'-endo base conformation in both purines and pyrimidines which enhances base stacking and makes the RNA more rigid. 2'-O-methylation has been proposed to stabilize the RNA and protect it from the attack of ribonucleases at higher temperatures [79].

In humans, the mapping of 2'-O-methylation in rRNA reveals most modifications to be present in comparable amounts for different cell lines. However, few specific sites show a different degree of modifications between HeLa, cervical cancer and HCT116, colon cancer cell lines [42]. This observation could mean that 2'-O-methylation in different cancers modify the functions of ribosomes to different extents. Lack of 2'-O-methylations has not been directly linked to any disease, however; box C/D snoRNAs have been implicated in different diseases.

\subsection{Box C/D Guide RNAs in Cancer}

The expression of a bulk of box C/D snoRNAs is altered in different cancers. SNORD50 guides methylation at C2848 and G2863 on $28 \mathrm{~S}$ rRNA and has been designated as a tumor suppressor gene for prostate, colon, and breast cancers $[23,24,80]$. Deletion of two base pairs in the locus of this snoRNA has been associated with prostate cancer [24]. Ectopic expression of this snoRNA gene is shown to reduce the tumorigenicity of prostate cancer cells that are marked by a reduced colony forming ability of two cell lines 22Rv1 and LNCaP [24]. While screening for genes that are sensitive to metabolic stress in diabetes and other metabolic syndromes, an independent study identified SNORD32a, SNORD33, and SNORD35a in Chinese Hamster ovary (CHO) cells and C2C12 mouse myoblasts [81]. Suppression of the three snoRNAs expression renders $\mathrm{C} 2 \mathrm{C} 12$ myoblasts resistant to Palmitate-induced and general 
apoptosis (also see Section 3.3) [81]. Although these experiments are carried out in different cell types, the finding that these snoRNAs are involved in response to general oxidative stress can also be applicable during oncogenesis. However, further investigation is needed to support this link. Increased and decreased expression of various snoRNAs and scaRNAs with known targets in $18 \mathrm{~S}$ rRNA, 28S rRNAs, and snRNAs, respectively have been linked to several types of leukemia, prostate cancer and multiple myeloma (reviewed in reference [44]) and also listed in Tables 3 and 4.

\subsection{Box C/D Guide RNAs in Genetic Disease}

The well-characterized study done on box C/D snoRNA is for Prader Willi syndrome (PWS) $[82,83]$. Mental retardation, muscle hypotonia, obesity, and shorter height are the disease phenotypes. Deregulation of two box C/D snoRNAs, SNORD115 and SNORD116 have been directly linked to this disease. SNORD115 and SNORD116 originate from chromosomal locus 15q11-q13, a region that contains several genes controlled by genomic imprinting. It is a phenomenon in which genes are expressed preferentially from one parental origin. Interestingly, these snoRNAs are remarkably modulated in PWS only when there is an inheritance from paternal 15q11-q13 deletion; however, their expression seems unchanged in the much less severe Angelman syndrome when inherited as a maternal 15q11-q13 deletion [84]. Both SNORD115 and SNORD116 are bona fide box C/D snoRNAs [82] which do not undergo hydrolysis to form smaller snoRNA products in either human or mouse brains, but their targets have not yet been found, and thus it is beyond the focus of this review for detailed discussion.

Recently, it has also been shown that 12 sno/scaRNAs with known methylation targets in U2 and U6 snRNAs are down-regulated in congenital heart defects [58]. As described in Section 2.2, along with the H/ACA scaRNAs several box C/D snoRNAs and scaRNAs are down-regulated in TOF [61]. These box C/D scaRNAs are guides for modifications on U2 snRNA (Table 4). Some of them are also predicted to guide rRNA modification but are not yet validated.

\subsection{Box C/D Guide RNAs in Other Disease}

As mentioned in Section 3.1, snoRNAs have also been associated with lipotoxicity, a metabolic stress associated with diabetes and obesity [81]. Increased levels of three box C/D snoRNAs, SNORD32a, SNORD33, and SNORD35a, were seen in CHO cells when they were exposed to fatty acids. snoRNAs were a surprise element in this study, which was carried out as a genetic screen in $\mathrm{CHO}$ cells using retroviral promoter trap mutagenesis to create single gene disruptions to select for cells, which could grow in a lipotoxic environment. One of the mutant cell lines, which grew in this environment, had a disruption in the locus for ribosomal protein L13a (RPL13a) [81]. There was no change in rRNA methylation in cells under lipotoxic stress although 12-13 bp in each of the three snoRNAs matched with potential sites in $18 \mathrm{~S}$ and $28 \mathrm{~S}$ rRNA. Interestingly, unlike their usual locations in the nucleolus, these snoRNAs accumulated in the cytoplasm in $\mathrm{C} 2 \mathrm{C} 12$ mouse myoblasts under lipotoxic conditions [81]. Knockdown of the three snoRNAs also reduced the amount of $\mathrm{H}_{2} \mathrm{O}_{2}$ derived reactive oxygen species in these cells and helped the cells evade apoptosis. These snoRNAs are also key players in an in vivo oxidation stress as mouse model studies show with lipopolysaccharide administration as compared with saline-treated mouse controls showed increased levels of these snoRNAs in liver [81].

In another case, patients with anterior cruciate ligament (ACL) injury show an increased level of snoRNAs SNORD38 and SNORD48 in their serum as compared with controls [85]. However, it is not clear if these are secreted in serum or released by damaged cells. Similar circulating snoRNAs, as well as other RNAs, are detected in serum in pancreatic cancers (reviewed in [86]). SNORD38 level is up-regulated in all ACL patients. However, the SNORD48 level is even higher in ACL patients with cartilage damage than the normal donors or patients with ACL but no cartilage damage. Thus, snoRNAs can also be used as a biomarker for early diagnosis of the cartilage damage associated with this disease [85]. 


\subsection{Box C/D Guide RNA Host Gene Deregulation in Disease}

Like box H/ACA RNA host genes, there are several genes that produce box C/D RNAs from their intronic regions and also not much work has been done to link host genes to their snoRNA regulation. Moreover, ribosomal protein genes very commonly serve as host genes for box C/D RNAs as well. RPS11 encodes SNORD35B that guides C4506 methylation on 28S rRNA. RPS11 protein is up-regulated in colorectal carcinoma [87] and down-regulated in staurosporine-induced apoptotic MCF7 breast cancer cell line [88]. This aberrant expression did not affect ribosome biogenesis in MCF7 cells pointing towards the fact that instead of the protein, the snoRNA encoded from its intron is playing a role in cancer. Recently, SNORD35B has also been found to be up-regulated in HNSCC [89]. RPL13A is another host gene encoding SNORD32, SNORD33A, and SNORD35A and deregulation of the host gene or snoRNAs are associated with different types of cancer [26,54] (also see Section 3.1). There is an array of ribosomal protein genes whose introns code for snoRNAs (Tables 3 and 4) that can cause disease. Additionally, the majority of these snoRNA encoding host genes are targets of Myc transcription factor in Drosophila [14] which is frequently up-regulated in different cancers.

GAS5 (Growth arrest-specific transcript 5) transcripts regulate both cell death and proliferation and are found to be reduced in both breast cancer and HNSCC compared to normal $[25,90]$. Additionally, SNORD44, which is one of the ten box C/D snoRNAs that are encoded in GAS5 introns, is also significantly associated with HNSCC prognosis [25].

Here, we have summarized the known box C/D snoRNAs and scaRNAs which have been observed to play a role in numerous diseases with their corresponding host genes and verified or predicted targets in Tables 3 and 4.

Table 3. Box C/D guide snoRNAs in human disease.

\begin{tabular}{|c|c|c|c|c|c|}
\hline Guide RNA & $\begin{array}{c}\text { Target } \\
\text { rRNA/snRNA } \\
\text { Position }\end{array}$ & Host Gene & $\begin{array}{l}\text { Disease Associated } \\
\text { with the RNA }\end{array}$ & $\begin{array}{c}\text { Level } \\
\text { Compared to } \\
\text { Normal }\end{array}$ & Ref. \\
\hline SNORD7 (Z30) & U6-A47 & $\begin{array}{l}\text { LINC02001 (long intergenic } \\
\text { non-protein coding RNA 2001) }\end{array}$ & $\begin{array}{c}\text { Tetralogy of Fallot (TOF), } \\
\text { a heart condition in } \\
\text { children }\end{array}$ & Down & {$[61]$} \\
\hline $\begin{array}{l}\text { SNORD8 } \\
(\mathrm{mgU6}-53)\end{array}$ & U6-A53 & $\begin{array}{l}\text { CHD8 (chromo-domain helicase } \\
\text { DNA binding protein } 8 \text { ) }\end{array}$ & TOF & Down & [61] \\
\hline $\begin{array}{l}\text { SNORD9 } \\
(\mathrm{mgU6}-53 \mathrm{~B})\end{array}$ & U6-A53 & CHD8 & TOF & Down & [61] \\
\hline $\begin{array}{l}\text { SNORD19 } \\
\text { (HBII-108) }\end{array}$ & $\begin{array}{c}\text { 18S-G683 } \\
(\mathrm{SNORD136)} *\end{array}$ & GNL3 (G protein nucleolar 3) & Colorectal cancer & Up & [91] \\
\hline $\begin{array}{l}\text { SNORD25 } \\
\text { (U25) }\end{array}$ & 18S-G1490 & $\begin{array}{c}\text { SNHG1 (small nucleolar RNA } \\
\text { host gene 1) }\end{array}$ & Multiple Myeloma & Up & [92] \\
\hline $\begin{array}{l}\text { SNORD27 } \\
\text { (U27) }\end{array}$ & 18S-A27 & SNHG1 & Multiple Myeloma & Up & [92] \\
\hline $\begin{array}{l}\text { SNORD28 } \\
\text { (U28) }\end{array}$ & 18S-C1391 & SNHG1 & Breast tumors & Up & [93] \\
\hline $\begin{array}{l}\text { SNORD30 } \\
\text { (U30) }\end{array}$ & $\begin{array}{l}28 \mathrm{~S}-\mathrm{A} 3804 \\
18 \mathrm{~S}-\mathrm{C} 1383\end{array}$ & SNHG1 & Multiple Myeloma & Up & [92] \\
\hline $\begin{array}{l}\text { SNORD31 } \\
\text { (U31) }\end{array}$ & 28S-G4166 & SNHG1 & Multiple Myeloma & Up & [92] \\
\hline $\begin{array}{l}\text { SNORD32 } \\
\text { (U32) }\end{array}$ & $\begin{array}{l}\text { 28S-A1511 } \\
\text { 18S-G1328 }\end{array}$ & RPL13 (ribosomal protein L13) & $\begin{array}{c}\text { Secondary plasma cell } \\
\text { leukemia }\end{array}$ & Down & [54] \\
\hline $\begin{array}{l}\text { SNORD33A } \\
\text { (U33A) }\end{array}$ & 18S-U1326 & RPL13 & NSCLC & Up & [26] \\
\hline $\begin{array}{l}\text { SNORD35A } \\
\text { (U35A) }\end{array}$ & 28S-C4506 & RPL13 & $\begin{array}{l}\text { Colorectal carcinomas, } \\
\text { Head and neck cancer }\end{array}$ & Up & {$[87,89]$} \\
\hline $\begin{array}{l}\text { SNORD35B } \\
\text { (U35B) }\end{array}$ & 28S-C4506 & RPS11 (ribosomal protein S11) & $\begin{array}{c}\text { Colorectal carcinomas, } \\
\text { HNSCC }\end{array}$ & Up & {$[87,89]$} \\
\hline
\end{tabular}


Table 3. Cont.

\begin{tabular}{|c|c|c|c|c|c|}
\hline Guide RNA & $\begin{array}{c}\text { Target } \\
\text { rRNA/snRNA } \\
\text { Position }\end{array}$ & Host Gene & $\begin{array}{l}\text { Disease Associated } \\
\text { with the RNA }\end{array}$ & $\begin{array}{c}\text { Level } \\
\text { Compared to } \\
\text { Normal }\end{array}$ & Ref. \\
\hline $\begin{array}{l}\text { SNORD38A } \\
\text { (U38A) } \\
\text { SNORD38B } \\
\text { (U38B) }\end{array}$ & 28S-A1858 & RPS8 (ribosomal protein S8) & ACL & Up & [85] \\
\hline $\begin{array}{l}\text { SNORD43 } \\
\text { (U43) }\end{array}$ & 18S-C1703 & RPL3 (ribosomal protein L3) & $\begin{array}{l}\text { Breast cancer and } \\
\text { HNSCC }\end{array}$ & $\begin{array}{l}\text { Patient-specific } \\
\text { variability }\end{array}$ & [25] \\
\hline $\begin{array}{l}\text { SNORD } 44 \\
\quad(\mathrm{U} 44)\end{array}$ & 18S-A166 & $\begin{array}{c}\text { GAS5 (Growth arrest-specific } \\
\text { transcript 5) }\end{array}$ & $\begin{array}{l}\text { Breast cancer and } \\
\text { HNSCC }\end{array}$ & Down & [25] \\
\hline $\begin{array}{l}\text { SNORD48 } \\
\text { (U48) }\end{array}$ & 28S-C2279 & $\begin{array}{l}\text { KIF24 (Kinesin Family Member } \\
\text { 24) }\end{array}$ & ACL & Up & [85] \\
\hline $\begin{array}{l}\text { SNORD50A } \\
\text { (U50) }\end{array}$ & $\begin{array}{l}\text { 28S-C2848, } \\
\text { 28S-G2863 }\end{array}$ & $\begin{array}{c}\text { SNHG5 (small nucleolar RNA } \\
\text { host gene 5) }\end{array}$ & $\begin{array}{l}\text { Breast cancer, prostate } \\
\text { cancer, colon cancer }\end{array}$ & Down & {$[23,24,80]$} \\
\hline $\begin{array}{l}\text { SNORD66 } \\
\text { (HBII-142) }\end{array}$ & $18 \mathrm{~S}-\mathrm{C} 1272$ & $\begin{array}{l}\text { EIF4G1 (Eukaryotic translation } \\
\text { initiation factor } 4 \text { gamma, 1) }\end{array}$ & NSCLC & Up & [26] \\
\hline $\begin{array}{l}\text { SNORD67 } \\
\text { (HBII-166) }\end{array}$ & U6-C60 & $\begin{array}{c}\text { CKAP5 (cytoskeleton associated } \\
\text { protein } 5 \text { ) }\end{array}$ & TOF & Down & [61] \\
\hline $\begin{array}{l}\text { SNORD71 } \\
\text { (HBII-239) }\end{array}$ & 5.8S-U14 & $\begin{array}{l}\text { AP1G1 (adaptor-related protein } \\
\text { complex } 1 \text { subunit gamma 1) }\end{array}$ & T cell lymphoma & Down & [55] \\
\hline $\begin{array}{l}\text { SNORD76 } \\
\text { (U76) }\end{array}$ & 28S-A2350 & GAS5 & $\begin{array}{c}\text { Hepatocellular } \\
\text { carcinoma, glioblastoma } \\
\text { and NSCLC }\end{array}$ & Up in NSCLC & {$[94,95]$} \\
\hline $\begin{array}{l}\text { SNORD78 } \\
\text { (U78) }\end{array}$ & 28S-G4593 & GAS5 & $\begin{array}{l}\text { Hepatocellular } \\
\text { carcinoma }\end{array}$ & Up & [96] \\
\hline $\begin{array}{l}\text { SNORD94 } \\
\text { (U94) }\end{array}$ & U6-C62 & $\begin{array}{c}\text { PTCD3 (pentatricopeptide repeat } \\
\text { domain 3) }\end{array}$ & TOF & Down & [61] \\
\hline $\begin{array}{l}\text { SNORD98 } \\
\text { (HBII-419) }\end{array}$ & 18S-G867 & $\begin{array}{l}\text { CCAR1 (cell division cycle and } \\
\text { apoptosis regulator 1) }\end{array}$ & Colorectal cancer & Up & [91] \\
\hline SNORD105B & 18S-U799 & PPAN (peter pan homolog) & Gastric cancer & $\mathrm{Up}$ & [97] \\
\hline
\end{tabular}

Table 4. Box C/D guide scaRNAs in human disease.

\begin{tabular}{|c|c|c|c|c|c|}
\hline Guide RNA & $\begin{array}{l}\text { Target snRNA } \\
\text { Position }\end{array}$ & Host Gene & $\begin{array}{l}\text { Disease Associated } \\
\text { with the RNA }\end{array}$ & $\begin{array}{c}\text { Level } \\
\text { Compared to } \\
\text { Normal }\end{array}$ & Ref. \\
\hline $\begin{array}{c}\text { scaRNA2 } \\
(\text { HBII-382) }\end{array}$ & $\begin{array}{l}\text { U2-G25 and } \\
\text { G61 }\end{array}$ & Independent transcriptional unit & $\begin{array}{c}\text { Congenital heart defect } \\
\text { and TOF }\end{array}$ & Down & {$[58,61]$} \\
\hline $\begin{array}{l}\text { scaRNA9 } \\
(\text { Z32) }\end{array}$ & $\mathrm{U} 2-\mathrm{G} 19, \mathrm{~A} 30$ & Centrosomal Protein 295 & $\begin{array}{l}\text { Chronic lymphocytic } \\
\text { leukemia and TOF }\end{array}$ & Down & {$[54,61]$} \\
\hline $\begin{array}{l}\text { scaRNA17 } \\
\text { (U91) }\end{array}$ & $\begin{array}{l}\mathrm{U} 4-\mathrm{C} 8 \text { and } \\
\mathrm{U} 12-\mathrm{G} 22\end{array}$ & $\begin{array}{c}\text { SNHG22 (small nucleolar RNA } \\
\text { host gene 22) }\end{array}$ & $\begin{array}{c}\text { Chronic lymphocytic } \\
\text { leukemia }\end{array}$ & Down & {$[54,98]$} \\
\hline
\end{tabular}

( ) alternative names used in the literature.

\section{Conclusions}

snoRNAs have been known for decades, mostly for their role in ribosomal biogenesis and modification. Recent developments in sequencing techniques have helped to detect snoRNAs and their further processed products. Many snoRNAs are processed into shorter functional forms like miRNA [99], but this process is still not fully understood. A recent study shows that human noncoding microRNA-1291 (hsa-miR-1291) is localized within the box H/ACA RNA snoRA34, and targets multidrug resistance-associated protein 1 (MRP1/ABCC1) mRNA 3'-untranslated region (3'UTR) [100].

The contribution of the non-coding RNAs to human disease is a relatively new area of research, predominantly based on the recent findings that their expression and function are often altered in diseases such as cancer, genetic, and neurological disorders $[28,29]$. So far, the mechanisms for to how snoRNA or snoRNA-derived molecules carry out their varied regulatory roles are not very clear and thus are an area for future research. Few questions that are critical to understanding the link between snoRNAs and host genes are: why are different snoRNAs that are encoded from the same host gene 
differentially altered in diseases? For example, SNORD32, SNORD33A, and SNORD35A although expressed from the same host gene RPL13A are differentially modulated in different carcinomas (see Table 3). Another host gene, SNHG1 encodes eight snoRNAs of which only a handful are up-regulated in multiple myeloma (see Table 3). It will be interesting to see if there is a finer regulation on which certain snoRNAs are up-regulated, or they are all up-regulated, and some can escape detection merely based on their half-lives. Additionally, a potential feedback loop, present between the host genes and their intronic snoRNAs, may also regulate either of their expressions under specific diseased states.

Still, there are many snoRNAs, in higher eukaryotes whose targets and functions are not yet known. These are called orphan snoRNAs. Target sequences for the orphan guides can possibly be present within mRNAs. Alteration in the guide RNA expression can trigger changes in the mRNA modification landscape and, consequently can alter protein translation. There are many open-ended questions like these, and the answers will require a combination of bioinformatics, biophysical and biochemical experimental approaches to provide understanding into the detailed macromolecular modulations that are induced by post-transcriptional nucleoside modifications. This will undoubtedly open up new avenues of research for better disease prognosis and therapeutic interventions.

Author Contributions: M.M. conceived the idea of the review; M.M. and M.D. designed and wrote the paper.

Funding: This work received no external funding.

Acknowledgments: We thank Prof. U. Thomas Meier for his critical comments on the review.

Conflicts of Interest: The authors declare no conflict of interest.

\section{References}

1. Blaby, I.K.; Majumder, M.; Chatterjee, K.; Jana, S.; Grosjean, H.; de Crecy-Lagard, V.; Gupta, R. Pseudouridine formation in archaeal RNAs: The case of Haloferax volcanii. RNA 2011, 17, 1367-1380. [CrossRef] [PubMed]

2. Bortolin, M.L.; Kiss, T. Human U19 intron-encoded snoRNA is processed from a long primary transcript that possesses little potential for protein coding. RNA 1998, 4, 445-454. [PubMed]

3. Decatur, W.A.; Fournier, M.J. rRNA modifications and ribosome function. Trends Biochem. Sci. 2002, 27, 344-351. [CrossRef]

4. Limbach, P.A.; Crain, P.F.; McCloskey, J.A. Summary: The modified nucleosides of RNA. Nucleic Acids Res. 1994, 22, 2183-2196. [CrossRef] [PubMed]

5. Ofengand, J. Ribosomal RNA pseudouridines and pseudouridine synthases. FEBS Lett. 2002, 514, 17-25. [CrossRef]

6. Tollervey, D.; Lehtonen, H.; Jansen, R.; Kern, H.; Hurt, E.C. Temperature-sensitive mutations demonstrate roles for yeast fibrillarin in pre-rRNA processing, pre-rRNA methylation, and ribosome assembly. Cell 1993, 72, 443-457. [CrossRef]

7. Cantara, W.A.; Crain, P.F.; Rozenski, J.; McCloskey, J.A.; Harris, K.A.; Zhang, X.; Vendeix, F.A.; Fabris, D.; Agris, P.F. The RNA Modification Database, RNAMDB: 2011 update. Nucleic Acids Res. 2011, 39, D195-D201. [CrossRef]

8. Bachellerie, J.P.; Cavaille, J.; Huttenhofer, A. The expanding snoRNA world. Biochimie 2002, 84, 775-790. [CrossRef]

9. Kiss, T. Small nucleolar RNA-guided post-transcriptional modification of cellular RNAs. EMBO J. 2001, 20, 3617-3622. [CrossRef]

10. Rashid, R.; Aittaleb, M.; Chen, Q.; Spiegel, K.; Demeler, B.; Li, H. Functional requirement for symmetric assembly of archaeal box C/D small ribonucleoprotein particles. J. Mol. Biol. 2003, 333, 295-306. [CrossRef]

11. Hamma, T.; Ferre-D'Amare, A.R. The box H/ACA ribonucleoprotein complex: Interplay of RNA and protein structures in post-transcriptional RNA modification. J. Biol. Chem. 2010, 285, 805-809. [CrossRef] [PubMed]

12. Terns, M.; Terns, R. Noncoding RNAs of the H/ACA family. Cold Spring Harb. Symp. Quant. Biol. 2006, 71, 395-405. [CrossRef] [PubMed]

13. Filipowicz, W.; Pogacic, V. Biogenesis of small nucleolar ribonucleoproteins. Curr. Opin. Cell Biol. 2002, 14, 319-327. [CrossRef] 
14. Herter, E.K.; Stauch, M.; Gallant, M.; Wolf, E.; Raabe, T.; Gallant, P. snoRNAs are a novel class of biologically relevant Myc targets. BMC Biol. 2015, 13, 25. [CrossRef] [PubMed]

15. Jorjani, H.; Kehr, S.; Jedlinski, D.J.; Gumienny, R.; Hertel, J.; Stadler, P.F.; Zavolan, M.; Gruber, A.R. An updated human snoRNAome. Nucleic Acids Res. 2016, 44, 5068-5082. [CrossRef] [PubMed]

16. Lestrade, L.; Weber, M.J. snoRNA-LBME-db, a comprehensive database of human H/ACA and C/D box snoRNAs. Nucleic Acids Res. 2006, 34, D158-D162. [CrossRef]

17. Dieci, G.; Preti, M.; Montanini, B. Eukaryotic snoRNAs: A paradigm for gene expression flexibility. Genomics 2009, 94, 83-88. [CrossRef]

18. Tollervey, D.; Kiss, T. Function and synthesis of small nucleolar RNAs. Curr. Opin. Cell. Biol. 1997, 9, 337-342. [CrossRef]

19. Smith, C.M.; Steitz, J.A. Classification of gas5 as a multi-small-nucleolar-RNA (snoRNA) host gene and a member of the $5^{\prime}$-terminal oligopyrimidine gene family reveals common features of snoRNA host genes. Mol. Cell. Biol. 1998, 18, 6897-6909. [CrossRef]

20. Askarian-Amiri, M.E.; Crawford, J.; French, J.D.; Smart, C.E.; Smith, M.A.; Clark, M.B.; Ru, K.; Mercer, T.R.; Thompson, E.R.; Lakhani, S.R.; et al. SNORD-host RNA Zfas1 is a regulator of mammary development and a potential marker for breast cancer. RNA 2011, 17, 878-891. [CrossRef]

21. Maxwell, E.S.; Fournier, M.J. The small nucleolar RNAs. Annu. Rev. Biochem. 1995, 64, 897-934. [CrossRef] [PubMed]

22. Yamashita, R.; Suzuki, Y.; Takeuchi, N.; Wakaguri, H.; Ueda, T.; Sugano, S.; Nakai, K. Comprehensive detection of human terminal oligo-pyrimidine (TOP) genes and analysis of their characteristics. Nucleic Acids Res. 2008, 36, 3707-3715. [CrossRef] [PubMed]

23. Dong, X.Y.; Guo, P.; Boyd, J.; Sun, X.; Li, Q.; Zhou, W.; Dong, J.T. Implication of snoRNA U50 in human breast cancer. J. Genet. Genom. 2009, 36, 447-454. [CrossRef]

24. Dong, X.Y.; Rodriguez, C.; Guo, P.; Sun, X.; Talbot, J.T.; Zhou, W.; Petros, J.; Li, Q.; Vessella, R.L.; Kibel, A.S.; et al. SnoRNA U50 is a candidate tumor suppressor gene at $6 \mathrm{q} 14.3$ with a mutation associated with clinically significant prostate cancer. Hum. Mol. Genet. 2008, 17, 1031-1042. [CrossRef] [PubMed]

25. Gee, H.E.; Buffa, F.M.; Camps, C.; Ramachandran, A.; Leek, R.; Taylor, M.; Patil, M.; Sheldon, H.; Betts, G.; Homer, J.; et al. The small-nucleolar RNAs commonly used for microRNA normalisation correlate with tumour pathology and prognosis. Br. J. Cancer 2011, 104, 1168-1177. [CrossRef] [PubMed]

26. Liao, J.; Yu, L.; Mei, Y.; Guarnera, M.; Shen, J.; Li, R.; Liu, Z.; Jiang, F. Small nucleolar RNA signatures as biomarkers for non-small-cell lung cancer. Mol. Cancer 2010, 9, 198. [CrossRef] [PubMed]

27. Williams, G.T.; Farzaneh, F. Are snoRNAs and snoRNA host genes new players in cancer? Nat. Rev. Cancer 2012, 12, 84-88. [CrossRef] [PubMed]

28. Esteller, M. Non-coding RNAs in human disease. Nat. Rev. Genet. 2011, 12, 861-874. [CrossRef] [PubMed]

29. McMahon, M.; Contreras, A.; Ruggero, D. Small RNAs with big implications: New insights into H/ACA snoRNA function and their role in human disease. Wiley Interdiscip. Rev. RNA 2015, 6, 173-189. [CrossRef] [PubMed]

30. Cohn, W.E. 5-Ribosyl uracil, a carbon-carbon ribofuranosyl nucleoside in ribonucleic acids. Biochim. Biophys. Acta 1959, 32, 569-571. [CrossRef]

31. Ganot, P.; Bortolin, M.L.; Kiss, T. Site-specific pseudouridine formation in preribosomal RNA is guided by small nucleolar RNAs. Cell 1997, 89, 799-809. [CrossRef]

32. Ni, J.; Tien, A.L.; Fournier, M.J. Small nucleolar RNAs direct site-specific synthesis of pseudouridine in ribosomal RNA. Cell 1997, 89, 565-573. [CrossRef]

33. Kiss, A.M.; Jady, B.E.; Bertrand, E.; Kiss, T. Human box H/ACA pseudouridylation guide RNA machinery. Mol. Cell. Biol. 2004, 24, 5797-5807. [CrossRef]

34. Baxter-Roshek, J.L.; Petrov, A.N.; Dinman, J.D. Optimization of ribosome structure and function by rRNA base modification. PLoS ONE 2007, 2, e174. [CrossRef] [PubMed]

35. Matera, A.G.; Terns, R.M.; Terns, M.P. Non-coding RNAs: Lessons from the small nuclear and small nucleolar RNAs. Nat. Rev. Mol. Cell Biol. 2007, 8, 209-220. [CrossRef]

36. Reichow, S.L.; Hamma, T.; Ferre-D'Amare, A.R.; Varani, G. The structure and function of small nucleolar ribonucleoproteins. Nucleic Acids Res. 2007, 35, 1452-1464. [CrossRef]

37. Jady, B.E.; Ketele, A.; Kiss, T. Human intron-encoded Alu RNAs are processed and packaged into Wdr79-associated nucleoplasmic box H/ACA RNPs. Genes Dev. 2012, 26, 1897-1910. [CrossRef] 
38. Ofengand, J.; Bakin, A. Mapping to nucleotide resolution of pseudouridine residues in large subunit ribosomal RNAs from representative eukaryotes, prokaryotes, archaebacteria, mitochondria and chloroplasts. J. Mol. Biol. 1997, 266, 246-268. [CrossRef]

39. Kierzek, E.; Malgowska, M.; Lisowiec, J.; Turner, D.H.; Gdaniec, Z.; Kierzek, R. The contribution of pseudouridine to stabilities and structure of RNAs. Nucleic Acids Res. 2014, 42, 3492-3501. [CrossRef]

40. Penzo, M.; Montanaro, L. Turning Uridines around: Role of rRNA Pseudouridylation in Ribosome Biogenesis and Ribosomal Function. Biomolecules 2018, 8, 38. [CrossRef]

41. Kehr, S.; Bartschat, S.; Tafer, H.; Stadler, P.F.; Hertel, J. Matching of Soulmates: Coevolution of snoRNAs and their targets. Mol. Biol. Evol. 2014, 31, 455-467. [CrossRef] [PubMed]

42. Krogh, N.; Jansson, M.D.; Hafner, S.J.; Tehler, D.; Birkedal, U.; Christensen-Dalsgaard, M.; Lund, A.H.; Nielsen, $\mathrm{H}$. Profiling of $2^{\prime}-\mathrm{O}-\mathrm{Me}$ in human rRNA reveals a subset of fractionally modified positions and provides evidence for ribosome heterogeneity. Nucleic Acids Res. 2016, 44, 7884-7895. [CrossRef] [PubMed]

43. Taoka, M.; Nobe, Y.; Yamaki, Y.; Sato, K.; Ishikawa, H.; Izumikawa, K.; Yamauchi, Y.; Hirota, K.; Nakayama, H.; Takahashi, N.; et al. Landscape of the complete RNA chemical modifications in the human $80 \mathrm{~S}$ ribosome. Nucleic Acids Res. 2018, 46, 9289-9298. [CrossRef] [PubMed]

44. Stepanov, G.A.; Filippova, J.A.; Komissarov, A.B.; Kuligina, E.V.; Richter, V.A.; Semenov, D.V. Regulatory role of small nucleolar RNAs in human diseases. BioMed Res. Int. 2015, 2015, 206849. [CrossRef] [PubMed]

45. Chang, L.S.; Lin, S.Y.; Lieu, A.S.; Wu, T.L. Differential expression of human 5S snoRNA genes. Biochem. Biophys. Res. Commun. 2002, 299, 196-200. [CrossRef]

46. Mei, Y.P.; Liao, J.P.; Shen, J.; Yu, L.; Liu, B.L.; Liu, L.; Li, R.Y.; Ji, L.; Dorsey, S.G.; Jiang, Z.R.; et al. Small nucleolar RNA 42 acts as an oncogene in lung tumorigenesis. Oncogene 2012, 31, 2794-2804. [CrossRef]

47. Okugawa, Y.; Toiyama, Y.; Toden, S.; Mitoma, H.; Nagasaka, T.; Tanaka, K.; Inoue, Y.; Kusunoki, M.; Boland, C.R.; Goel, A. Clinical significance of SNORA42 as an oncogene and a prognostic biomarker in colorectal cancer. Gut 2017, 66, 107-117. [CrossRef]

48. Yoshida, K.; Toden, S.; Weng, W.; Shigeyasu, K.; Miyoshi, J.; Turner, J.; Nagasaka, T.; Ma, Y.; Takayama, T.; Fujiwara, T.; et al. SNORA21-An Oncogenic Small Nucleolar RNA, with a Prognostic Biomarker Potential in Human Colorectal Cancer. eBioMedicine 2017, 22, 68-77. [CrossRef]

49. Li, G.; He, Y.; Liu, X.; Zheng, Z.; Zhang, M.; Qin, F.; Lan, X. Small nucleolar RNA 47 promotes tumorigenesis by regulating EMT markers in hepatocellular carcinoma. Minerva Med. 2017, 108, 396-404. [CrossRef]

50. Wu, L.; Zheng, J.; Chen, P.; Liu, Q.; Yuan, Y. Small nucleolar RNA ACA11 promotes proliferation, migration and invasion in hepatocellular carcinoma by targeting the PI3K/AKT signaling pathway. Biomed. Pharmacother. 2017, 90, 705-712. [CrossRef]

51. Qin, Y.; Meng, L.; Fu, Y.; Quan, Z.; Ma, M.; Weng, M.; Zhang, Z.; Gao, C.; Shi, X.; Han, K. SNORA74B gene silencing inhibits gallbladder cancer cells by inducing PHLPP and suppressing Akt/mTOR signaling. Oncotarget 2017, 8, 19980-19996. [CrossRef] [PubMed]

52. Bellodi, C.; McMahon, M.; Contreras, A.; Juliano, D.; Kopmar, N.; Nakamura, T.; Maltby, D.; Burlingame, A.; Savage, S.A.; Shimamura, A.; et al. H/ACA small RNA dysfunctions in disease reveal key roles for noncoding RNA modifications in hematopoietic stem cell differentiation. Cell Rep. 2013, 3, 1493-1502. [CrossRef] [PubMed]

53. Ronchetti, D.; Mosca, L.; Cutrona, G.; Tuana, G.; Gentile, M.; Fabris, S.; Agnelli, L.; Ciceri, G.; Matis, S.; Massucco, C.; et al. Small nucleolar RNAs as new biomarkers in chronic lymphocytic leukemia. BMC Med. Genom. 2013, 6, 27. [CrossRef] [PubMed]

54. Ronchetti, D.; Todoerti, K.; Tuana, G.; Agnelli, L.; Mosca, L.; Lionetti, M.; Fabris, S.; Colapietro, P.; Miozzo, M.; Ferrarini, M.; et al. The expression pattern of small nucleolar and small Cajal body-specific RNAs characterizes distinct molecular subtypes of multiple myeloma. Blood Cancer J. 2012, 2, e96. [CrossRef] [PubMed]

55. Valleron, W.; Ysebaert, L.; Berquet, L.; Fataccioli, V.; Quelen, C.; Martin, A.; Parrens, M.; Lamant, L.; de Leval, L.; Gisselbrecht, C.; et al. Small nucleolar RNA expression profiling identifies potential prognostic markers in peripheral T-cell lymphoma. Blood 2012, 120, 3997-4005. [CrossRef] [PubMed]

56. Lawrence, M.S.; Stojanov, P.; Mermel, C.H.; Robinson, J.T.; Garraway, L.A.; Golub, T.R.; Meyerson, M.; Gabriel, S.B.; Lander, E.S.; Getz, G. Discovery and saturation analysis of cancer genes across 21 tumour types. Nature 2014, 505, 495-501. [CrossRef] [PubMed] 
57. Liang, F.; Qu, H.; Lin, Q.; Yang, Y.; Ruan, X.; Zhang, B.; Liu, Y.; Yu, C.; Zhang, H.; Fang, X.; et al. Molecular biomarkers screened by next-generation RNA sequencing for non-sentinel lymph node status prediction in breast cancer patients with metastatic sentinel lymph nodes. World J. Surg. Oncol. 2015, 13, 258. [CrossRef] [PubMed]

58. Patil, P.; Kibiryeva, N.; Uechi, T.; Marshall, J.; O’Brien, J.E., Jr.; Artman, M.; Kenmochi, N.; Bittel, D.C. scaRNAs regulate splicing and vertebrate heart development. Biochim. Biophys. Acta 2015, 1852, 1619-1629. [CrossRef] [PubMed]

59. Parry, E.M.; Alder, J.K.; Lee, S.S.; Phillips, J.A., 3rd; Loyd, J.E.; Duggal, P.; Armanios, M. Decreased dyskerin levels as a mechanism of telomere shortening in X-linked dyskeratosis congenita. J. Med. Genet. 2011, 48, 327-333. [CrossRef] [PubMed]

60. Piekna-Przybylska, D.; Decatur, W.A.; Fournier, M.J. The 3D rRNA modification maps database: With interactive tools for ribosome analysis. Nucleic Acids Res. 2008, 36, D178-D183. [CrossRef] [PubMed]

61. Nagasawa, C.; Ogren, A.; Kibiryeva, N.; Marshall, J.; O’Brien, J.E.; Kenmochi, N.; Bittel, D.C. The Role of scaRNAs in Adjusting Alternative mRNA Splicing in Heart Development. J. Cardiovasc. Dev. Dis. 2018, 5, 26. [CrossRef] [PubMed]

62. DiGiacomo, V.; Meruelo, D. Looking into laminin receptor: Critical discussion regarding the non-integrin 37/67-kDa laminin receptor/RPSA protein. Biol. Rev. Camb. Philos. Soc. 2016, 91, 288-310. [CrossRef] [PubMed]

63. Boria, I.; Garelli, E.; Gazda, H.T.; Aspesi, A.; Quarello, P.; Pavesi, E.; Ferrante, D.; Meerpohl, J.J.; Kartal, M.; Da Costa, L.; et al. The ribosomal basis of Diamond-Blackfan Anemia: Mutation and database update. Hum. Mutat. 2010, 31, 1269-1279. [CrossRef] [PubMed]

64. Garcon, L.; Ge, J.; Manjunath, S.H.; Mills, J.A.; Apicella, M.; Parikh, S.; Sullivan, L.M.; Podsakoff, G.M.; Gadue, P.; French, D.L.; et al. Ribosomal and hematopoietic defects in induced pluripotent stem cells derived from Diamond Blackfan anemia patients. Blood 2013, 122, 912-921. [CrossRef] [PubMed]

65. Trahan, C.; Dragon, F. Dyskeratosis congenita mutations in the H/ACA domain of human telomerase RNA affect its assembly into a pre-RNP. RNA 2009, 15, 235-243. [CrossRef]

66. Schulten, H.J.; Bangash, M.; Karim, S.; Dallol, A.; Hussein, D.; Merdad, A.; Al-Thoubaity, F.K.; Al-Maghrabi, J.; Jamal, A.; Al-Ghamdi, F.; et al. Comprehensive molecular biomarker identification in breast cancer brain metastases. J. Transl. Med. 2017, 15, 269. [CrossRef]

67. Cui, L.; Nakano, K.; Obchoei, S.; Setoguchi, K.; Matsumoto, M.; Yamamoto, T.; Obika, S.; Shimada, K.; Hiraoka, N. Small Nucleolar Noncoding RNA SNORA23, Up-Regulated in Human Pancreatic Ductal Adenocarcinoma, Regulates Expression of Spectrin Repeat-Containing Nuclear Envelope 2 to Promote Growth and Metastasis of Xenograft Tumors in Mice. Gastroenterology 2017, 153, 292-306. [CrossRef]

68. Zhou, C.; Zang, D.; Jin, Y.; Wu, H.; Liu, Z.; Du, J.; Zhang, J. Mutation in ribosomal protein L21 underlies hereditary hypotrichosis simplex. Hum. Mutat. 2011, 32, 710-714. [CrossRef]

69. Steinbusch, M.M.; Fang, Y.; Milner, P.I.; Clegg, P.D.; Young, D.A.; Welting, T.J.; Peffers, M.J. Serum snoRNAs as biomarkers for joint ageing and post traumatic osteoarthritis. Sci. Rep. 2017, 7, 43558. [CrossRef]

70. Bosco, A.; Ehteshami, S.; Panyala, S.; Martinez, F.D. Interferon regulatory factor 7 is a major hub connecting interferon-mediated responses in virus-induced asthma exacerbations in vivo. J. Allergy Clin. Immunol. 2012, 129, 88-94. [CrossRef]

71. Irizar, H.; Munoz-Culla, M.; Saenz-Cuesta, M.; Osorio-Querejeta, I.; Sepulveda, L.; Castillo-Trivino, T.; Prada, A.; Lopez de Munain, A.; Olascoaga, J.; Otaegui, D. Identification of ncRNAs as potential therapeutic targets in multiple sclerosis through differential ncRNA-mRNA network analysis. BMC Genom. 2015, 16, 250. [CrossRef] [PubMed]

72. Mannoor, K.; Shen, J.; Liao, J.; Liu, Z.; Jiang, F. Small nucleolar RNA signatures of lung tumor-initiating cells. Mol. Cancer 2014, 13, 104. [CrossRef] [PubMed]

73. Lan, T.; Ma, W.; Hong, Z.; Wu, L.; Chen, X.; Yuan, Y. Long non-coding RNA small nucleolar RNA host gene 12 (SNHG12) promotes tumorigenesis and metastasis by targeting miR-199a/b-5p in hepatocellular carcinoma. J. Exp. Clin. Cancer Res. 2017, 36, 11. [CrossRef] [PubMed]

74. Hirano, T.; Yoshikawa, R.; Harada, H.; Harada, Y.; Ishida, A.; Yamazaki, T. Long noncoding RNA, CCDC26, controls myeloid leukemia cell growth through regulation of KIT expression. Mol. Cancer 2015, 14, 90. [CrossRef] 
75. Alawi, F.; Lin, P. Dyskerin is required for tumor cell growth through mechanisms that are independent of its role in telomerase and only partially related to its function in precursor rRNA processing. Mol. Carcinog. 2011, 50, 334-345. [CrossRef] [PubMed]

76. Deryusheva, S.; Gall, J.G. Orchestrated positioning of post-transcriptional modifications at the branch point recognition region of U2 snRNA. RNA 2018, 24, 30-42. [CrossRef] [PubMed]

77. Weiss, K.; Terhal, P.A.; Cohen, L.; Bruccoleri, M.; Irving, M.; Martinez, A.F.; Rosenfeld, J.A.; Machol, K.; Yang, Y.; Liu, P.; et al. De Novo Mutations in CHD4, an ATP-Dependent Chromatin Remodeler Gene, Cause an Intellectual Disability Syndrome with Distinctive Dysmorphisms. Am. J. Hum. Genet. 2016, 99, 934-941. [CrossRef] [PubMed]

78. Marnef, A.; Richard, P.; Pinzon, N.; Kiss, T. Targeting vertebrate intron-encoded box C/D 2'-O-methylation guide RNAs into the Cajal body. Nucleic Acids Res. 2014, 42, 6616-6629. [CrossRef]

79. Vare, V.Y.; Eruysal, E.R.; Narendran, A.; Sarachan, K.L.; Agris, P.F. Chemical and Conformational Diversity of Modified Nucleosides Affects tRNA Structure and Function. Biomolecules 2017, 7, 29. [CrossRef] [PubMed]

80. Pacilli, A.; Ceccarelli, C.; Trere, D.; Montanaro, L. SnoRNA U50 levels are regulated by cell proliferation and rRNA transcription. Int. J. Mol. Sci. 2013, 14, 14923-14935. [CrossRef] [PubMed]

81. Michel, C.I.; Holley, C.L.; Scruggs, B.S.; Sidhu, R.; Brookheart, R.T.; Listenberger, L.L.; Behlke, M.A.; Ory, D.S.; Schaffer, J.E. Small nucleolar RNAs U32a, U33, and U35a are critical mediators of metabolic stress. Cell Metab. 2011, 14, 33-44. [CrossRef] [PubMed]

82. Bortolin-Cavaille, M.L.; Cavaille, J. The SNORD115 (H/MBII-52) and SNORD116 (H/MBII-85) gene clusters at the imprinted Prader-Willi locus generate canonical box C/D snoRNAs. Nucleic Acids Res. 2012, 40, 6800-6807. [CrossRef] [PubMed]

83. Kishore, S.; Stamm, S. The snoRNA HBII-52 regulates alternative splicing of the serotonin receptor $2 \mathrm{C}$. Science 2006, 311, 230-232. [CrossRef] [PubMed]

84. Cavaille, J.; Seitz, H.; Paulsen, M.; Ferguson-Smith, A.C.; Bachellerie, J.P. Identification of tandemlyrepeated C/D snoRNA genes at the imprinted human 14q32 domain reminiscent of those at the Prader-Willi/Angelman syndrome region. Hum. Mol. Genet. 2002, 11, 1527-1538. [CrossRef] [PubMed]

85. Zhang, L.; Yang, M.; Marks, P.; White, L.M.; Hurtig, M.; Mi, Q.S.; Divine, G.; Gibson, G. Serum non-coding RNAs as biomarkers for osteoarthritis progression after ACL injury. Osteoarthritis Cartilage 2012, 20, 1631-1637. [CrossRef] [PubMed]

86. Kishikawa, T.; Otsuka, M.; Ohno, M.; Yoshikawa, T.; Takata, A.; Koike, K. Circulating RNAs as new biomarkers for detecting pancreatic cancer. World J. Gastroenterol. 2015, 21, 8527-8540. [CrossRef]

87. Kasai, H.; Nadano, D.; Hidaka, E.; Higuchi, K.; Kawakubo, M.; Sato, T.A.; Nakayama, J. Differential expression of ribosomal proteins in human normal and neoplastic colorectum. J. Histochem. Cytochem. 2003, 51, 567-574. [CrossRef]

88. Nadano, D.; Ishihara, G.; Aoki, C.; Yoshinaka, T.; Irie, S.; Sato, T.A. Preparation and characterization of antibodies against human ribosomal proteins: Heterogeneous expression of S11 and S30 in a panel of human cancer cell lines. Jpn. J. Cancer Res. 2000, 91, 802-810. [CrossRef]

89. Zou, A.E.; Ku, J.; Honda, T.K.; Yu, V.; Kuo, S.Z.; Zheng, H.; Xuan, Y.; Saad, M.A.; Hinton, A.; Brumund, K.T.; et al. Transcriptome sequencing uncovers novel long noncoding and small nucleolar RNAs dysregulated in head and neck squamous cell carcinoma. RNA 2015, 21, 1122-1134. [CrossRef]

90. Mourtada-Maarabouni, M.; Pickard, M.R.; Hedge, V.L.; Farzaneh, F.; Williams, G.T. GAS5, a non-proteincoding RNA, controls apoptosis and is downregulated in breast cancer. Oncogene 2009, 28, 195-208. [CrossRef]

91. Xu, L.; Ziegelbauer, J.; Wang, R.; Wu, W.W.; Shen, R.F.; Juhl, H.; Zhang, Y.; Rosenberg, A. Distinct Profiles for Mitochondrial t-RNAs and Small Nucleolar RNAs in Locally Invasive and Metastatic Colorectal Cancer. Clin. Cancer Res. 2016, 22, 773-784. [CrossRef] [PubMed]

92. Lopez-Corral, L.; Mateos, M.V.; Corchete, L.A.; Sarasquete, M.E.; de la Rubia, J.; de Arriba, F.; Lahuerta, J.J.; Garcia-Sanz, R.; San Miguel, J.F.; Gutierrez, N.C. Genomic analysis of high-risk smoldering multiple myeloma. Haematologica 2012, 97, 1439-1443. [CrossRef] [PubMed]

93. Yu, F.; Bracken, C.P.; Pillman, K.A.; Lawrence, D.M.; Goodall, G.J.; Callen, D.F.; Neilsen, P.M. p53 Represses the Oncogenic Sno-MiR-28 Derived from a SnoRNA. PLoS ONE 2015, 10, e0129190. [CrossRef] [PubMed]

94. Chen, L.; Han, L.; Wei, J.; Zhang, K.; Shi, Z.; Duan, R.; Li, S.; Zhou, X.; Pu, P.; Zhang, J.; et al. SNORD76, a box C/D snoRNA, acts as a tumor suppressor in glioblastoma. Sci. Rep. 2015, 5, 8588. [CrossRef] [PubMed] 
95. Wu, L.; Chang, L.; Wang, H.; Ma, W.; Peng, Q.; Yuan, Y. Clinical significance of C/D box small nucleolar RNA $\mathrm{U} 76$ as an oncogene and a prognostic biomarker in hepatocellular carcinoma. Clin. Res. Hepatol. Gastroenterol. 2018, 42, 82-91. [CrossRef] [PubMed]

96. Ma, P.; Wang, H.; Han, L.; Jing, W.; Zhou, X.; Liu, Z. Up-regulation of small nucleolar RNA 78 is correlated with aggressive phenotype and poor prognosis of hepatocellular carcinoma. Tumour Biol. 2016. [CrossRef] [PubMed]

97. Zhang, C.; Zhao, L.M.; Wu, H.; Tian, G.; Dai, S.L.; Zhao, R.Y.; Shan, B.E. C/D-Box Snord105b Promotes Tumorigenesis in Gastric Cancer via ALDOA/C-Myc Pathway. Cell. Physiol. Biochem. 2018, 45, 2471-2482. [CrossRef] [PubMed]

98. Krogh, N.; Kongsbak-Wismann, M.; Geisler, C.; Nielsen, H. Substoichiometric ribose methylations in spliceosomal snRNAs. Org. Biomol. Chem. 2017, 15, 8872-8876. [CrossRef] [PubMed]

99. Brameier, M.; Herwig, A.; Reinhardt, R.; Walter, L.; Gruber, J. Human box C/D snoRNAs with miRNA like functions: Expanding the range of regulatory RNAs. Nucleic Acids Res. 2011, 39, 675-686. [CrossRef]

100. Pan, Y.Z.; Zhou, A.; Hu, Z.; Yu, A.M. Small nucleolar RNA-derived microRNA hsa-miR-1291 modulates cellular drug disposition through direct targeting of ABC transporter ABCC1. Drug Metab. Dispos. Biol. Fate Chem. 2013, 41, 1744-1751. [CrossRef]

(C) 2018 by the authors. Licensee MDPI, Basel, Switzerland. This article is an open access article distributed under the terms and conditions of the Creative Commons Attribution (CC BY) license (http:/ / creativecommons.org/licenses/by/4.0/). 